\title{
On the Method of Investigating Human Exposure to Nonuniform Magnetic Field
}

\author{
Kenichi Yamazaki Member (CRIEPI) \\ Tadashi Kawamoto Member (CRIEPI) \\ Hideo Fujinami Member (CRIEPI) \\ Tsukasa Shigemitsu Member (CRIEPI)
}

Keywords : ELF magnetic field, induced current, anatomically correct human model, impedance method, guidelines

Regarding compliance testing with existing guidelines on human exposure to ELF (extremely low frequency) magnetic fields, such as ICNIRP's (International Commission on Non-Ionizing Radiation Protection), the nonuniformity of the fields has been one of the major concerns. This is due to the fact that guideline-level exposures are generally encountered in the direct vicinity of magnetic field sources, such as electric power facilities and electric appliances. According to the guidelines, when the measured maximum magnetic fields exceed the specified field level (reference level), induced currents inside human bodies are to be investigated to check their conformity. However, this calculation still needs verification and requires massive computational resources, which are not readily applicable under practical exposure conditions. Therefore, a simple and relevant method of assessing nonuniform magnetic field exposure is highly desirable.

In this paper, a method of obtaining an equivalent uniform magnetic field using a coefficient ("normalized induction factor"

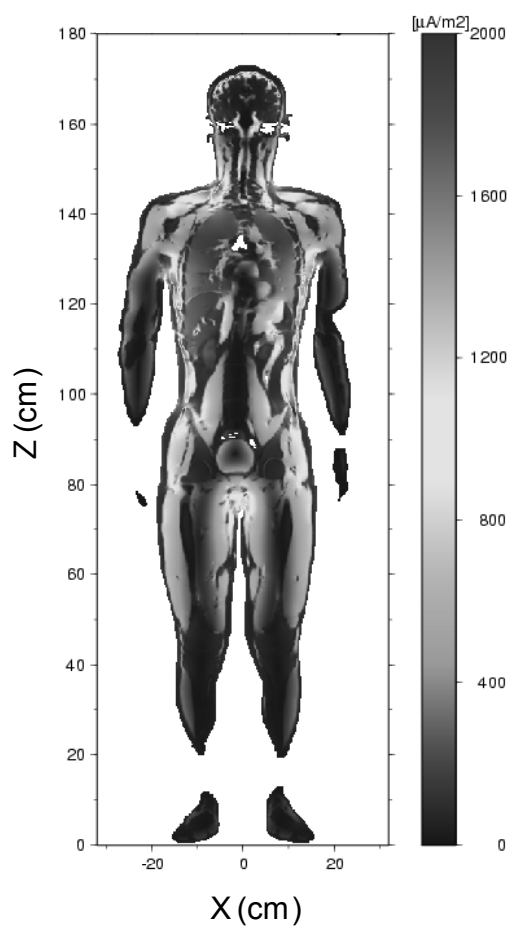

Fig. 1. Human model and example of distribution of induced current density at cross section for coronal (y-direction) uniform magnetic field $(1 \mathrm{mT}, 50 \mathrm{~Hz})$ exposure expressed as Eq. (1)) is investigated using a numerical calculation of induced current in anatomically correct human models.

$$
K_{J}=\frac{J_{\text {max_non-uniform }}}{J_{\text {max_uniform }}},
$$

where $J_{\max \_ \text {uniform }}$ and $J_{\max \_n o n-\text { nniform }}$ are the maximum induced currents for uniform and nonuniform exposures, respectively, when the maximum magnetic fields in the model are the same for both exposures.

Induced currents inside anatomically correct human models, which are developed by NICT (National Institute of Information and Communication Technology) and universities, were calculated for uniform and nonuniform magnetic field exposures (Fig. 1). The calculation method adopted was the impedance method. For nonuniform exposure, line currents closely placed near the human model were used with variable intervals between the model and the line currents. Then, the normalized induction factors were calculated using Eq. (1) (Fig. 2). The results are also compared with those of a US study. In addition, to assess the obtained coefficient easily, a simple analytical method based on a homogenous spherical model was proposed and verified (Fig. 2). The results obtained in the study are of practical importance for assessing compliance with guidelines.

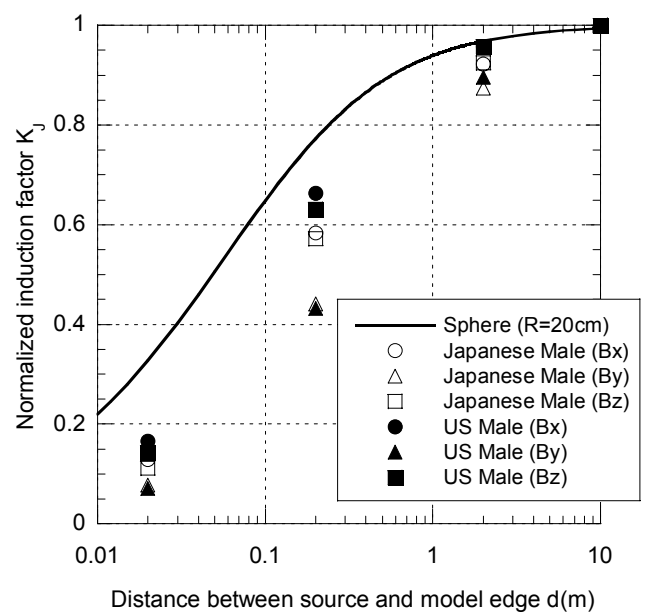

Fig. 2. Normalized induction factors for anatomically correct human models (US model and Japanese male model); The solid curve shows values estimated using a simple formula for a homogeneous spherical model (radius of $20 \mathrm{~cm}$ ), which traces the maximum of the induction factors for the anatomically correct human models 


\title{
非一様磁界中の人体ばく露評価手法に関する考察

$\begin{array}{lllll}\text { 正員 山崎 } & \text { 健一* } & \text { 正 員 河本 } & \text { 正* } \\ \text { 正 員 藤波 } & \text { 秀雄* } & \text { 正 員 } & \text { 重光 } & \text { 司** }\end{array}$

\author{
On the Method of Investigating Human Exposure to Nonuniform Magnetic Field \\ Kenichi Yamazaki*, Member, Tadashi Kawamoto*, Member, Hideo Fujinami*, Member, \\ Tsukasa Shigemitsu**, Member
}

\begin{abstract}
Regarding compliance testing with existing guidelines on human exposure to ELF (extremely low frequency) magnetic fields, the nonuniformity of the fields has been one of the major concerns since guideline-level exposures are generally encountered in the direct vicinity of magnetic field sources such as electric power facilities and electric appliances. According to the guidelines, when the measured maximum magnetic fields exceed the specified field level, induced currents inside human bodies are to be investigated to check their conformity. However, this calculation still needs verification and requires massive computational resources, which are not readily applicable under practical exposure conditions. Therefore, a simple and relevant method of assessing nonuniform magnetic field exposure is highly desirable. In this paper, a method of obtaining an equivalent uniform magnetic field using a coefficient (the normalized induction factor) is investigated using a numerical calculation of induced current in anatomically correct human models. In addition, to assess the obtained coefficient easily, a simple method using a spherical model was proposed.
\end{abstract}

キーワード : 低周波磁界, 誘導電流, 人体詳細モデル, インピーダンス法, ガイドライン

Keywords : ELF magnetic field, induced current, anatomically correct human model, impedance method, guidelines

\section{1. はじめに}

電磁界の安全性評価の拠りどころとして，人体防護指針 が広く認識されるようになっている(1) (5)。特に 1998 年に発 行された ICNIRP（国際非電離放射線防護委員会）によるガ イドライン (1)は，欧州理事会勧告（公衆ばく露）(2)や欧州指 令 (職業ばく露) (3)として採用されるなど，もっとも影響力 のある防護指針とみなされている。このガイドラインでは, 概补 $100 \mathrm{kHz}$ 以下の低周波磁界ばく露に対し, 体内に誘導さ れる電流の, 神経や筋への刺激作用が指標となっており, この作用の生体反応の閾值に安全率を見込んだ体内誘導電 流密度の值が，「基本制限=遵守すべき值」として示されて いる。また，基本制限に対応する測定可能な物理量として， 磁界の「参考レベル」が示されている。参考レベルを満た すことにより, 基本制限を満たすことが保障され, 参考レ ベルを超えた場合でも, 誘導電流を評価し, 基本制限を満 たすことを示せば適合性が示される。このように，体内誘

\footnotetext{
* (財) 電力中央研究所

于240-0196 横須賀市長坂 2-6-1

Central Research Institute of Electric Power Industry

2-6-1, Nagasaka, Yokosuka 240-0196

** $\bar{\top} 270-1194$ 我孫子市我孫子 1646

1646, Abiko, Abiko 270-1166
}

導量を遵守すべき量とし, 測定可能な磁界の参考值を併記 する 2 段階構成は，2002 年に発行された IEEE（米国電気電 子学会）規格 ${ }^{(4)}$ や 2000 年に発行されたオランダ Health Council $^{(5)}$ による防護指針においても同様であり, 本稿では主 として ICNIRP ガイドラインを対象とする。なお, IEEE 規 格では体内誘導量の指標として, 誘導電流密度ではなく誘 導電界が用いられている。

防護指針では，誘導電流から参考レベルの導出において 安全側の仮定が置かれ, 磁界と生体とのカップリングが最 大となる一様磁界が仮定されている。この換算の際に仮定 する人体モデルとして, 以前は解析解の存在する均質円断 面や均質楕円断面が多く用いられていたが, 近年の計算機 能力の向上等に伴い, 2 3 $\mathrm{mm}$ 程度の解像度を持つ人体の 解剖学的詳細モデル(6) (10)を用いた計算が報告され( ${ }^{(8)}(10)$, これらが防護指針の換算の根拠としても採用されるように なっている。たとえば, ICNIRP ガイドラインでは, カナダ Victoria 大学の Stuchly らのグループによる, 数值人体モデ ルを用いた計算の，初期（1994 年）の論文 ${ }^{(11)}$ が他のモデル による結果と併せて適用され，また同グループの 1997 年の 論文 ${ }^{(12)}$ の数值計算結果は, オランダの防護指針における磁 界と誘導電流の換算の根拠として用いられている。一方で 
は，議論の透明性の観点や再現の困難さから，このような 人体詳細モデルを用いた数值計算は，防護指針の根拠とし ての採用にはなじまないとする考え方もあり，2002 年の IEEE 規格 ${ }^{(4)}$ では, 解析解が存在する均質楕円断面モデルの 使用が明示されている。

防護指針を実際の磁界ばく露評価に適用する場合，まず 人体が占有する空間における最大磁界を評価し，防護指針 の参考レベルとの比較を行う。これを超えた場合でも，電 流路や機器などの磁界発生源のごく近傍などでは, 磁界の 非一様性の度合が高く磁界と人体とのカップリングが減少 することから，一様磁界が仮定され導出された防護指針の 参考レベルを緩和，あるいは誘導電流を再評価することが 正当化される。

しかしながら，あらゆる非一様磁界ばく露に対して，そ の都度人体内誘導電流の数值計算評価を行うことは現実的 ではなく, 非一様磁界ばく露評価のより簡便な手法の導入 が望まれている。このような観点から, 非一様磁界ばく露 の合理的な評価手法の開発の試みがなされており ${ }^{(13) \sim(18),}$

IEC (国際電気標準会議) においても標準化の対象となって いる(19) (21)。また, 著者らにおいても同様の検討を行ってお り ${ }^{(22)}$, 本論文においても，より簡便で妥当な非一様磁界ば く露評価手法の開発を目的とする。はじめに，防護指針の 基本制限と直接比較する手法の問題点を示し, 次にこれを 解決する手段として, 磁界の非一様性の指標となる係数を 用いて等価な一様磁界を求める手法を示す。次に, 日本人 人体詳細モデルを対象として，インピーダンス法による誘 導電流計算を行いこれらの指標を算出するとともに，他の 機関による評価結果との比較を行い，本手法の利点と妥当 性を示す。最後に, 磁界の非一様性の指標となる係数を簡 便に求める手法を示し, 簡便で合理的な非一様磁界ばく露 評価手法開発への足がかりとする。

\section{2. 非一様磁界ばく露の評価手法}

\section{$\langle 2 \cdot 1\rangle$ 防護指針との適合性評価における体内誘導電流} 評価の問題点防護指針では, 非一様磁界ばく露の評価 において, 人体が占有する空間における最大磁界が参考レ ベルを超えた場合, そのばく露状況における人体モデル内 誘導電流を評価し, 基本制限との比較を行う手順を想定し ている。誘導電流計算を行う際, 人体モデルを設定する必 要があるが，前述のとおり，モデルが明示されている IEEE 規格を除き，ICNIRP ガイドラインなどの防護指針では，基 本制限（誘導電流密度）と磁界参考レベルの換算に用いら れた人体モデルの諸元が明示されていない。このため, 防護 指針の基本制限との適合性評価を行うユーザ側で，任意の 人体モデルを設定し計算を行うことになり，防護指針との 整合性に問題が生じることが避けられない†。
磁界による誘導電流計算において, 使用する人体モデル の違い（分割のボクセルサイズの違いなども含む）が, 評 価結果に与える影響は非常に大きく, 同じ磁界条件に対し ても, 人体モデルの違いを反映して誘導電流の評価結果は 一桁程度にわたり大きくばらつくことがわかっている(23)。

これは, 各組織の導電率についての限られた情報や, 曲面

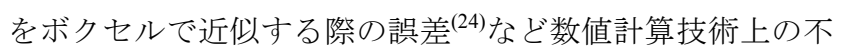
可避な制約にも起因寸るが，一般に同じ大きさの磁界に対 して, 均質円断面など単純なモデルでは誘導電流が小さく 評価され, 解像度が高い詳細な人体モデルでは誘導電流が 大きく評価される(23)。このことは, 使用する人体モデルに 任意性があると説得力を持って真の誘導電流の值を示すこ とが困難であるという問題点を示している。

なお, ICNIRP ガイドラインでは, 非一様磁界ばく露に対 して全身の磁界の平均值を求めて, 磁界の参考レベルと比 較する方法も示されており, その有効性については 4 章で 考察する。

〈2·2〉磁界の非一様性の指標の導入 前節で述べた 誘導電流を直接評価することの問題点を解決する方法とし て, 誘導電流と磁界との換算の拠りどころを防護指針に求 める方法がある。すなわち, 防護指針においては, すでに 基本制限（誘導電流密度）と参考レベル（磁界）の対応が 示されているため, この関係を出発点とし, これと矛盾な く議論を進めることは, 説得力の観点からも有利である。 防護指針に示されたこの関係は, 一様磁界ばく露に対する ものであるので, これを基本として, 非一様磁界ばく露に 対しては, 磁界の非一様性を表す指標を導入する。これに より, 非一様性磁界を等価な一様磁界に換算することがで きれば，防護指針における参考レベルと比較することが可 能となる。

この考え方は, Bracken・Dawson ${ }^{(18)}$ や誘導電流評価法に関 する IEC 規格 ${ }^{(20)}$ ，ならびに著者ら ${ }^{(22)}$ が志向しており，いず れも, 仮定するモデルに対し, 非一様磁界ばく露における 最大誘導電流を評価し, これと同じ最大誘導電流が生じる 等価な一様磁界を得ようとするものである。

非一様磁界を等価な一様磁界一換算する係数は, 「規格 化誘導係数（Normalized Induction Factor）(18)(22)」（あるいは 「結合係数 (Coupling Factor) ${ }^{(20) 」)}$ と呼ばれ，(1)式により 定義される。

$$
K_{J}=\frac{\left(\frac{J_{\max _{n} \text { non-uniform }}}{B_{\max \_n o n-\text { unifrom }}}\right)}{\left(\frac{J_{\text {max_uniform }_{\text {nor }}}}{B_{\text {uniform }}}\right)}
$$

すなわち, 規格化誘導係数 $K_{J}$ は, 「一様磁界ばく露におけ る, 磁界の大きさ $B_{\text {uniform }}$ と最大誘導電流 $J_{\max \text {-uniform }}$ の比」に
†例えば ICNIRP ガイドラインにおいて, $50 \mathrm{~Hz}$ の一様磁界への公衆 ばく露の場合, 基本制限の誘導電流密度は $2 \mathrm{~mA} / \mathrm{m}^{2}$, これに対応す る磁界の参考レベルは $0.1 \mathrm{mT}$ である。しかしながら, ユーザーが 任意に設定する人体モデルによる計算では, 同じ $50 \mathrm{~Hz} 0.1 \mathrm{mT}$ の
一樣磁界を与えても, 通常 $2 \mathrm{~mA} / \mathrm{m}^{2}$ とはならない。ICNIRP では, そのばらつきも想定し, 人体モデルの多様性も許容しているものと 思われるが, 使用する人体モデルを変えることにより, 誘導電流の 評価值が変わるため, 結果的に評価に恣意性が入る余地が生じる。 
対する「非一様磁界ばく露における，モデル内最大磁界 $B_{\text {max_non-uniform }}$ と最大誘導電流 $J_{\max \_n o n-u n i f o r m}$ の比」である。こ の係数は, 発生源とモデル端との距離 $d$ の関数となり, 発 生源から十分遠方での, 磁界が一様とみなせる領域では $K_{J}=$ 1 に, 発生源近傍では磁界の非一様性の度合を反映して $K_{J}=$ 0 に近づく。

非一様磁界中のモデル内での最大磁界の大きさが，一様 磁界と等しい条件 $\left(B_{\max \text { nnon-uniform }}=B_{\text {uniform }}\right)$ では, 規格化誘 導係数 $K_{J}$ は,

$$
K_{J}=\frac{J_{\max \_n o n-\text { uniform }}}{J_{\text {max_uniform }}} .
$$

となり，あるばく露状況に対する規格化誘導係数の算出に は(2)式が用いられる。一方, 一様および非一様磁界ばく露 に対し，モデル内に生じる最大誘導電流密度が等しい条件 $\left(J_{\max \_n o n-\text { uniform }}=J_{\max \_ \text {uniform }}\right)$ では,

$$
B_{\text {uniform }}=K_{J} \times B_{\text {max_non-unifrom }}
$$

となり, 既知の規格化誘導係数を用いて非一様磁界から等 価な一様磁界を算出する際には( 3 )式の関係が用いられる。

\section{3. 人体詳細モデルにおける誘導電流計算}

\section{〈3・1〉 インピーダンス法による誘導電流計算コード}

規格化誘導係数 $K_{J}$ を指標とする非一様磁界評価手法につ いて種々の検討を行うため，人体詳細モデルを用いて誘導 電流計算を行い，規格化誘導係数 $K_{J}$ を算出した。

低周波領域では，電磁界の波長が人体よりも十分に長く， 準静的近似が可能となり, 電界と磁界を分離して扱うこと ができる。また誘導電流による 2 次磁界の影響を無視する ことができる。本研究では, 数值計算法としてインピーダ ンス法を用いる。インピーダンス法は，人体を抵抗からな る立方体形状のセル（ボクセルと呼ばれる）によりモデル 化し，モデル内の電磁界を回路網の電圧・電流に置き換え て, 回路網方程式を解く手法であり ${ }^{(25) \sim(30)}$, SPFD（スカラ 一ポテンシャル有限差分）法(9)(10)(12)(28)(31)(32) と並んで, ボク セルデータを用いた誘導電流計算に多く用いられている。 インピーダンス法は, SPFD 法と比べ, 未知数の数や計算速 度に不利な点があるが，作用項としてベクトルポテンシャ ルではなく, 扱いが容易な磁束密度を用いることができ, 磁界分布測定值に基づく評価が可能(27)などの利点がある。 なお最近では，ボクセルデータによる人体詳細モデルに対 して, 高速多重極表面電荷法が適用され, さらなる高速・ 大容量化が図られた報告がある ${ }^{(33)}$ 。

計算においては，対象のモデルを複数のボクセルでモデ ル化し, 各ボクセルに導電率 $\sigma$ 与え, ボクセルの各辺には インピーダンス $Z$ ，ボクセルの各表面にはループ電流 $I$ を定 義する。この際, インピーダンス $Z$ は, その辺を共有する 4 つのボクセルの各導電率のの平均值とする。

変動磁界により, 各ループにはファラデーの法則に基づ く誘導起電力が生じ, あるボクセルの面 $(x-y$ 平面) に生じ
る起電力 $V$ は

$$
V=-j \omega B_{n} \Delta x \Delta y
$$

となる。ここに $\Delta x, \Delta y$ はボクセル辺長, $B_{n}$ はボクセルの面 に直交する磁界成分である。以上のように定義したインピ ーダンス $Z$ とループ電流 $I$ (未知量) を用いて, 各ループに おける電圧降下と誘導起電力が等しくなるような閉路方程 式を作成し, すべての閉路方程式を連立させて解くことに より各ループ電流を求めた。得られたループ電流より, 同 じ辺を共有する 4 つのループ電流の和をとり, これを各辺 の電流とした (空気のボクセルは $\sigma=0$ とした)。各ボクセル の中心に定義する電流は, 同方向の 4 つの辺電流の平均值 とし, ボクセルの断面積で除すことにより, 誘導電流密度 を求めた。さらに誘導電界については, この誘導電流密度 をそのボクセルの導電率ので除すことにより得た。なお, 磁 束密度は各ループ電流中心で定義し, ループ内で一定とし た。

連立方程式の解法には, 記憶容量を大きく確保せずにプ ログラムの実装が容易な, 逐次過緩和（SOR: Successive Over-Relaxation）法を用いた。SOR の反復開始時に, 空気領 域とモデルとの境界面のループ電流值を計算しておき，こ れを初期值とし，それ以外の内部のセルの境界面では 0 を 初期值とした。SOR によるループ電流の解の更新の際には, モデル境界面の電流は更新せず，内部のみを更新した。作 成したプログラムは, 解析解がある一様磁界中の均質球な らびに 2 層球モデルに対して適用し, 解析解との比較によ りあらかじめその妥当性を検証した。

〈3.2〉人体詳細モデル人体詳細モデルとして, 独 立行政法人通信総合研究所（現在, 独立行政法人情報通信 研究機構), 北里大学, 慶応義塾大学, 東京都立大学 (現在, 首都大学東京）の共同開発による日本人男女の数值人体モ デルデータベース ${ }^{(6)(7)}$ を使用した。このモデルのボクセルサ イズは $2 \mathrm{~mm}$, 総有効ボクセル数（空気を除く） は約 800 万 (男性モデル) および約 630 万（女性モデル), 身長は, 男 性モデル $173 \mathrm{~cm}$, 女性モデル $160 \mathrm{~cm}$ である。モデルの各組 織に割り当てる導電率については, 出典によりさまざまな 值が存在するが, Gabriel らの研究に基づくデータ ${ }^{(34)}$ がよく 用いられている。本研究においても, Gabriel らの值を使用 し, Gabriel により值が示されていない組織（唾液線, 十二 指腸, 食道, 胆囊, 卵巣, 膵臓, 睪丸, 気管, 子宮, 歯) については, 類似の組織の導電率等を勘案し, 導電率の值 を決定した。計算に使用した各組織の導電率の值を Table 1 に示す。

〈3·3〉－様磁界中における誘導電流評価適用する 非一様磁界のばく露評価手法では，一様磁界中の誘導電流 が基本となる。非一様磁界中の誘導電流評価に先立ち, 一 様磁界中における誘導電流計算を行った。ばく露磁界の方 向として, 人体詳細モデルの側面方向 $(x$ 方向 $)$, 正面方向 $(y$ 方向), および垂直 (人体直立) 方向 $(z$ 方向 $)$ の 3 通り とした。誘導量評価の指標として, 誘導電流密度および誘 導電界のそれぞれについて, 全身のボクセルデータの「最 
Table 1. Conductivity of tissues used for calculations $(\mathrm{S} / \mathrm{m})$.

小脳 Cerebellum 0.10, 脳脊髄液 CSF 2.00, 角膜 Cornea 0.4, 眼球 Eye tissue (Sclera) 1.50 , 灰白質 Gray Matter 0.10, 視床下部 Hypothalamus 0.08 , 水晶 体 Lens 0.25 , 松果体 Pineal Gland 0.08 , 下垂体 Pituitary 0.08 , 唾液腺 Salivary Gland 0.35 , 視床 Thalamus 0.08 , 舌 Tongue 0.30 , 白質 White Matter 0.06 , 副腎 Adrenals 0.35 , 膀胱 Bladder 0.20, 乳房脂肪 Breast fat* 0.06 , 大 腸Large Intestine 0.10 , 大腸内容物 Large Int est ine Contents 0.35 , 十二指腸 Duodenum 0.10, 食道 Esophagus 0.10, 胆汁 Bile 1.40, 胆囊 Gall Bladder 0.10 , 心臟 Heart 0.10 , 腎臟 Kidney 0.10, 肝臓 Liver 0.07, 肺 Lung 0.14, 卵 单 Ovary* 0.10 , 膵臓 Pancreas 0.35 , 前立腺 Prostat $\mathrm{e}^{+} 0.40$, 小腸 Small Intestine 0.50, 脾臓 Spleen 0.10, 胃 Stomach 0.50, 胃内容物 Stomach Contents 0.35 , 腱 Tendon 0.30 , 睪丸Test is ${ }^{+} 0.35$, 甲状腺 Thyroid 0.50 , 気管 Trachea 0.10 , 尿 Urine 0.70 , 子宮 Uterus* 0.10 , 空気(体内空間) Air(Internal) 0.00 , 血液 Blood 0.70 , 皮質骨 Cortical Bone 0.02, 骨髄海綿骨 Bone Marrow/Cancellous Bone 0.06, 軟骨 Cartilage 0.18, 脂肪 Fat 0.04, 筋肉 Muscle 0.35, 神経(脊髄) Nerve (Spinal Cord) 0.03 , 皮膚 Skin 0.10, 歯 Tooth 0.02 , 勒带 Ligament 0.30, 小腸内容物 Small Intestine Contents 0.35 , 横隔膜 Diaphragm 0.35, 精囊 Seminal Vesicle ${ }^{+} 0.35$, 海綿体 Cavernous Body ${ }^{+} 0.35$, 腔 Vagina* $0.35,\left(^{+}\right.$:Male only, ${ }^{*}$ : Female only $)$

大值」および「 $99 \%$ 值」，電流方向に直交する「 $1 \mathrm{~cm}^{2}$ 断面 平均の最大值」, および電流方向に直交する $「 1 \mathrm{~cm}^{2}$ 断面平 均の 99\%值」, の 4 つの評価指標について算出した。これら の評価指標の意味や位置づけについては 4 章で詳細を述べ る。 $1 \mathrm{~cm}^{2}$ 断面の誘導電流の平均值については, ボクセル中 心に求めた誘導電流の直交各成分について, これに直交す る周囲 $5 \times 5$ のセル（面積が $1 \mathrm{~cm}^{2}$ となる）に対し平均化を 行い, 最後に 3 成分の自乗和の平方根を取ることにより求 めた。また，空気との境界では，空気のボクセルを除外し て平均化した（この場合，断面積は $1 \mathrm{~cm}^{2}$ とはならない)。

$0.1 \mathrm{mT}, 50 \mathrm{~Hz}$ の一様磁界に対する誘導電流・電界の各評 価指標の計算結果を Table 2 に, 男性人体モデルと正面方向 ( $y$ 方向) の磁界ばく露に対する $y$ 方向の中心付近の断面 (モ デルの領域の $y$ 方向を $-16 \mathrm{~cm} \sim+16 \mathrm{~cm}$ に割り当てた時の, $y=1.9 \mathrm{~cm}$ の断面）における誘導電流密度分布の例を Fig. 1 に示す。なお, 計算における SOR の加速係数は 1.97 を使用, 収束判定条件として, 最新解と前段階の解との差 (絶対値) の, 前段階の解に対する割合が, $10^{-6}$ 以下となった場合に反 復更新を終了させた。1 ケースあたりの計算時間は最大約 24 時間であった（CPU : Pentium 3.20 GHz，メモリ容量 3GB を使用)。最大誘導電流密度は, 男性モデルの場合 3.72 $\mathrm{mA} / \mathrm{m}^{2}$, 女性モデルで $2.77 \mathrm{~mA} / \mathrm{m}^{2}$ (ともに人体側面方向磁 界の場合, 脳脊髄液において）であった。最大誘導電流に 対して，他の評価指標を用いることにより最大誘導電流の 值は小さくなり，例えば男性モデルの場合，最大誘導電流 $3.72 \mathrm{~mA} / \mathrm{m}^{2}$ に対して, $1 \mathrm{~cm}^{2}$ 断面の平均值は $2.59 \mathrm{~mA} / \mathrm{m}^{2}, 99 \%$ 值は $0.84 \mathrm{~mA} / \mathrm{m}^{2}, 1 \mathrm{~cm}^{2}$ 断面の平均值の $99 \%$ 值は $0.78 \mathrm{~mA} / \mathrm{m}^{2}$ となり,この順に小さくなる傾向であった。なお, これら の数值計算結果は, 磁界の非一様性の指標となる係数（規 格化誘導係数）の算出に使用するものであり，本手法では これらの絶対值については論じない。また, Table 2 では, 文献(18)での結果との比較を併せて行っている。同文献で は, 身長 $177 \mathrm{~cm}, 3.6 \mathrm{~mm}$ の解像度の米国人男性モデル (Brooks モデル) に対し, SPFD 法により誘導電界 $\left(1 \mathrm{~cm}^{2}\right.$ 平均の最大值および $1 \mathrm{~cm}^{2}$ 平均の $99 \%$ 值) が評価されたもの でここでは $60 \mathrm{~Hz}$ の結果より $5 / 6$ を乗じて $50 \mathrm{~Hz}$ での值に
Table 2. Induced current density and induced electric field calculated in anatomically correct human model exposed to $0.1 \mathrm{mT}, 50 \mathrm{~Hz}$ uniform magnetic field.

\begin{tabular}{|c|c|c|c|c|c|c|c|c|c|}
\hline & & \multicolumn{4}{|c|}{ Induced Current Density $\left(\mathrm{mA} / \mathrm{m}^{2}\right)$} & \multicolumn{4}{|c|}{ Induced Electric Field $(\mathrm{mV} / \mathrm{m})$} \\
\hline & & $\begin{array}{l}\text { Voxel } \\
\text { Max }\end{array}$ & $\begin{array}{c}\text { Voxel } \\
99 \%\end{array}$ & $\begin{array}{c}1 \mathrm{~cm}^{2} \text { avg } \\
\operatorname{Max}\end{array}$ & $\begin{array}{c}1 \mathrm{~cm}^{2} \text { avg } \\
99 \%\end{array}$ & $\begin{array}{l}\text { Voxel } \\
\text { Max }\end{array}$ & $\begin{array}{c}\text { Voxel } \\
99 \%\end{array}$ & $\begin{array}{c}1 \mathrm{~cm}^{2} \text { avg } \\
\operatorname{Max}\end{array}$ & $\begin{array}{c}1 \mathrm{~cm}^{2} \text { avg } \\
99 \%\end{array}$ \\
\hline Japanese & $\mathrm{Bx}$ & 3.72 & 0.84 & 2.59 & 0.78 & 128.0 & 8.7 & 35.6 & 5.4 \\
\hline \multirow[t]{2}{*}{ Male } & By & 2.80 & 1.16 & 1.88 & 1.04 & 79.3 & 12.4 & 27.4 & 8.2 \\
\hline & $\mathrm{Bz}$ & 2.10 & 0.63 & 1.52 & 0.58 & 60.0 & 7.5 & 32.7 & 5.0 \\
\hline Japanese & $\mathrm{Bx}$ & 2.77 & 0.67 & 2.49 & 0.61 & 98.9 & 7.2 & 32.5 & 4.7 \\
\hline \multirow[t]{2}{*}{ Female } & By & 2.38 & 0.88 & 1.97 & 0.78 & 68.6 & 10.5 & 30.4 & 7.0 \\
\hline & $\mathrm{Bz}$ & 1.86 & 0.48 & 1.06 & 0.43 & 60.1 & 6.0 & 22.3 & 4.0 \\
\hline \multirow[t]{3}{*}{ US Male } & $\mathrm{Bx}$ & & & & & & & 20.9 & 3.7 \\
\hline & By & & & & & & & 20.9 & 6.4 \\
\hline & $\mathrm{Bz}$ & & & & & & & 13.5 & 3.6 \\
\hline
\end{tabular}

* Results from Ref. (18)

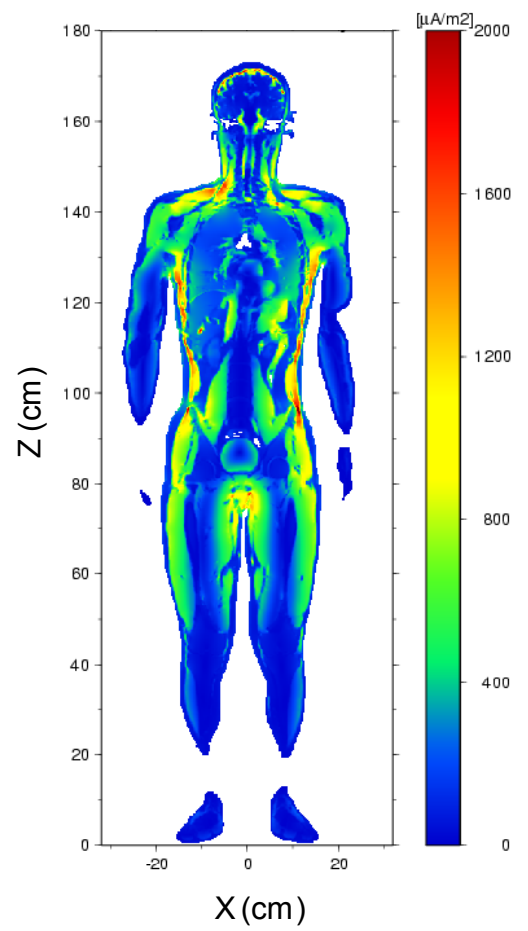

Fig. 1. Human model and example of distribution of induced current density at cross section $(y=1.9 \mathrm{~cm})$ for coronal $\left(B_{y}\right)$ uniform magnetic field $(1 \mathrm{mT}, 50 \mathrm{~Hz})$ exposure.

換算している。同文献では, 著者らによる日本人男性モデ ルでの結果に対し，27\%〜 59\%低く評価される結果であっ た。

〈3.4〉 非一様磁界中における誘導電流評価 次に, 非一様磁界中における誘導電流評価を行った。非一様磁界 を模擬する磁界発生源として, 比較が可能なように文献(18) で用いられた条件と同じ十分に長い単線電流路を仮定し, Fig. 2 に示すとおり, 人体詳細モデルの中心断面において, 側面方向 $(x$ 方向 $)$, 正面方向 $(y$ 方向 $)$, および垂直方向 $(z$ 方向）の 3 通りの磁界方向となるように電流路の近傍に人 体詳細モデルを配置した。垂直方向（ $z$ 方向）については, 心臓中心部の高さ（日本人男性モデルでは高さ $125.6 \mathrm{~cm}$, 日本人女性モデルでは $118.6 \mathrm{~cm}$ の位置) に電流路があるも のとした。モデル端（発生源に最も近い面の座標を基準と 


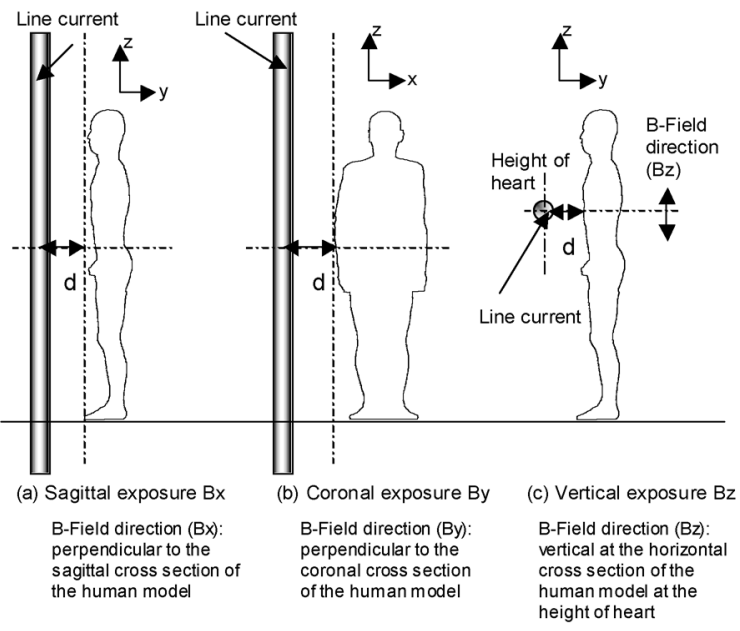

Fig. 2. Sources and human models. (a) sagittal exposure $B x$,

(b) coronal exposure $B y,(c)$ vertical exposure $B z$.

する。例えば Fig. 2(a)の $x$ 方向磁界のばく露条件では, つま 先の最先端の $y$ 座標）と単線電流路との間の距離 $d$ を $2 \mathrm{~cm}$, $20 \mathrm{~cm}, 2 \mathrm{~m}$ の 3 通りとし, 誘導電流・電界を計算した。こ のとき評価指標は, 一様磁界評価のときと同じ「ボクセル 最大值」および「ボクセル $99 \%$ 值」, 「1 $\mathrm{cm}^{2}$ 断面平均の最大 值」, 「1 $\mathrm{cm}^{2}$ 断面平均の $99 \%$ 值」の 4 種類である。単線電流 路の電流值は, 距離 $d$ の位置（人体モデル端部）の磁界が 一様磁界 $(0.1 \mathrm{mT})$ と等しくなるように与えた $(d=2 \mathrm{~cm}$ ： $10 \mathrm{~A}, d=20 \mathrm{~cm}: 100 \mathrm{~A}, d=2 \mathrm{~m}: 1000 \mathrm{~A})$ 。なお，人体モデ ルの中心ではなく，端部で磁界条件を規定することは，「人 体防護指針の評価における人体が占有する空間における最 大磁界評価」に対応するものである。誘導電界および誘導 電流密度のそれぞれ 4 つの評価指標それぞれについて, (2) 式にしたがい, 非一様磁界ばく露の計算結果の, 先に行っ た一様磁界に対する計算結果に対する割合を求め, 規格化 誘導係数 $K_{J}$ を算出した。

数值計算により求めた, 規格化誘導係数 $K_{J}$ の比較を Fig. 3, Fig. 4 に示す。Fig. 3(a),(b)では, 側面方向（ $x$ 方向）磁界 ばく露に対し，それぞれ日本人男性，日本人女性の詳細モ デルを対象に，算出した誘導電界，誘導電流の前述の各評 価指標（「ボクセル最大值」「「ボクセル $99 \%$ 值」,「 $1 \mathrm{~cm}^{2}$ 断 面平均の最大值」，「 $1 \mathrm{~cm}^{2}$ 断面平均の $99 \%$ 値」) に対する規格 化誘導係数の比較を行っている。また, Fig. 4 では, 文献(18) において指標として用いられた，誘導電界の $「 1 \mathrm{~cm}^{2}$ 断面平 均の 99\%值」について, 米国人詳細モデルと日本人男性詳 細モデルとの比較を，3 方向それぞれの磁界ばく露条件に対 して行っている。なお，Fig. 3, Fig. 4 中の球モデルに対する 規格化誘導係数については次節で述べる。

得られた結果より，発生源からの距離が近いほど，規格 化誘導係数が小さくなるという共通の傾向が得られている (Fig. 3)。たとえば, 発生源から $2 \mathrm{~cm}$ の位置では, 係数の值 は $0.1 \sim 0.2$ 程度であり，モデル（男女モデル）や指標間（8 種類の指標について検討）の差は小さい。発生源から遠ざ かるにつれ，磁界分布は一様に近づき，すなわち係数は 1

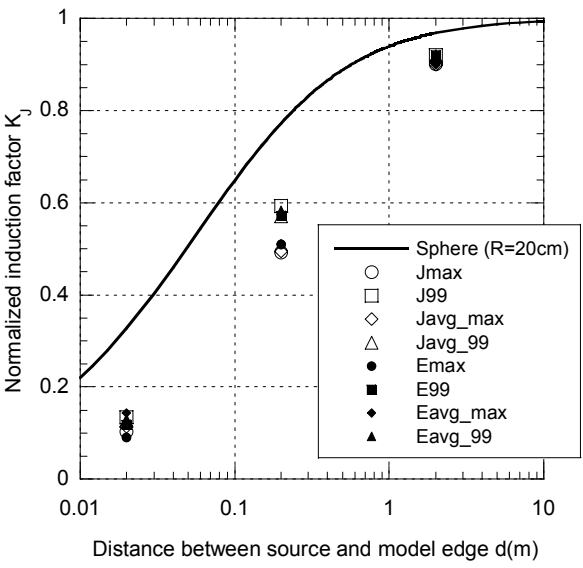

(a) Japanese male model

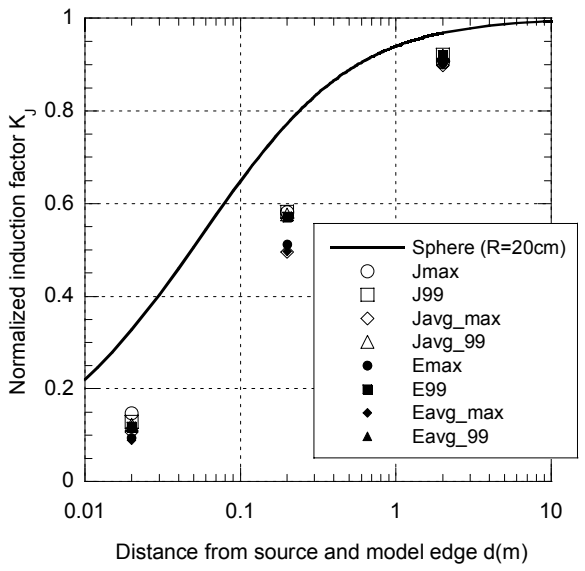

(b) Japanese female model

Fig. 3. Normalized induction factors for several parameters in Japanese male (a) and female (b) models, and homogeneous sphere (radius of $20 \mathrm{~cm}$ ). Case of sagittal exposure. $J$ : induced current density, $E$ : induced electric field, "max": maximum voxel value, "99": 99 percentile voxel value, “avg_max": max of $1 \mathrm{~cm}^{2}$ average, “avg_99”: 99 percentile value of $1 \mathrm{~cm}^{2}$ average.

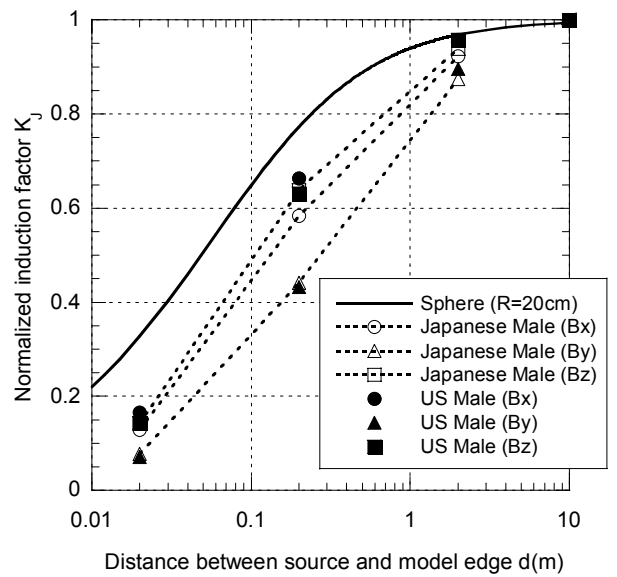

Fig. 4. Normalized induction factors for US and Japanese male models, and homogeneous sphere (radius of $20 \mathrm{~cm}$ ). The factors are based on induced electric fields, 99 percentile value of $1 \mathrm{~cm}^{2}$ average. 
に近づく。今回の計算では， $2 \mathrm{~m}$ 離れた位置ではいずれも 0.9 程度であった。誘導電流の值そのものを扱う場合, Table 2 に示した一様磁界の計算例のように, 用いる指標によって 大きく值が異なるのに対し, 磁界の非一様性の指標である 規格化誘導係数に対しては，これらの差がわずかとなるこ とが特徵である。

同様に, 米国人モデルを用いた文献(18)の計算結果と今回 の日本人モデルの計算結果との比較においても (Fig. 4), 人 体モデルは異なるものの, 規格化誘導係数を指標として用 いることにより，モデル間の差異はわずかになり，また係 数の距離特性の傾向もよく一致した。なお, 発生源の近傍 において, Fig. 2(b)の配置の正面方向ばく露時の誘導係数の 值が低いものになっている。この理由の解釈として，文献 (18)では, 最大磁界が腕の部分に存在し, ここでの断面が小 さいため誘導される電流が小さくなることを挙げている。

〈3.5〉均質球を用いた簡易評価手法 前節までの検 討において, 誘導電流・電界を指標としたばく露磁界の非 一様性を表す規格化誘導係数は, モデルの差異や評価指標 への依存性が小さく, 単線電流路からの距離により決定さ れることを示した。モデルへの依存性が小さいということ は，単純形状のモデルに対しても同様の傾向が得られるこ とが期待され，著者らの研究の目標とする簡便で妥当な非 一様磁界ばく露評価法の開発に道が開けるものとなる。本 節では，人体詳細モデルに対する規格化誘導係数の距離特 性を，単純形状のモデルを用いてより簡便に評価する手法 について検討する。

ここでは単純形状の評価モデルとして均質球(17)(22)を用い る。これは，他の検討で用いられている均質円断面 ${ }^{(20)}$ や均 質楕円断面 ${ }^{(18)}$ のモデルに比べ汎用性が高く, 評価式が存在 する利点を考慮するものである。単線電流路と均質球（半 径 $R$ ) の端部との距離が $d$ 離れている場合の規格化誘導係数 $K_{J}$ は, 距離 $d$ の関数として次の評価式により表現できる。

$$
K_{J}(d)=\frac{2 d}{R}\left(\frac{d+R}{R} \ln \frac{d+R}{d}-1\right)
$$

この式は, Swanson ${ }^{(14)}$ が示した単線電流路近傍の方形断面 への誘導量の評価式からの類推により導出したものであ り，数值計算との比較により妥当性を確認している ${ }^{(22)}$ 。

半径 $R$ の均質球を，単線電流路からの距離 $d$ の位置（均 質球端部までの距離）に配置した場合の，規格化誘導係数 $K_{J}$ の距離 $d$ に対する特性を, (5)式により評価した結果を Fig. 5 に示す。用いる均質球の大きさ（半径 $R$ ) の与え方つ いては任意性があるため, ここでは, $R=10 \mathrm{~cm}, 15 \mathrm{~cm}, 20 \mathrm{~cm}$, $30 \mathrm{~cm}$ ，および $50 \mathrm{~cm}$ についてプロットしている。半径 $R$ を 小さくすることにより, 同じ距離 $d$ における規格化誘導係 数は増加し, 半径を大きくすることにより規格化誘導係数 は減少する。適当な $R$ を選ぶことにより，前節までの検討 における, 人体詳細モデルに対する規格化誘導係数の距離 $d$ に対する特性をよく模擬できることがわかる。ここでは， 詳細モデルの規格化誘導係数の上限を安全側に評価するこ とを主眼として, 均質球の半径として $R=20 \mathrm{~cm}$ を用いた場

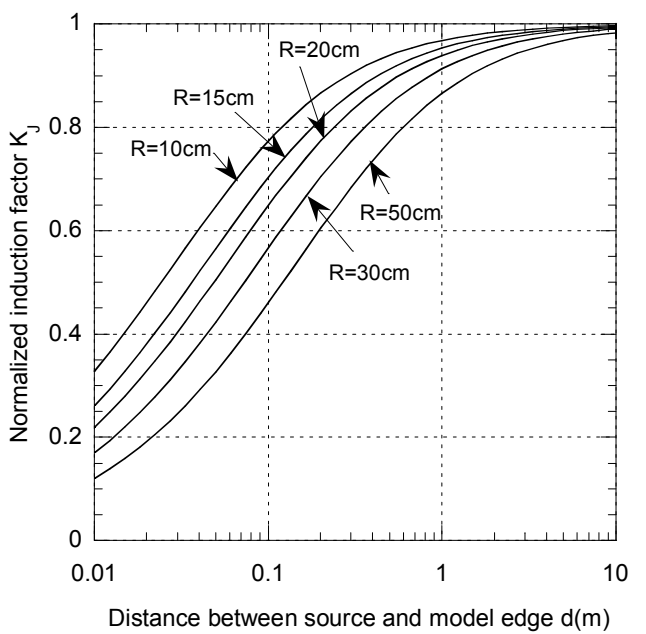

Fig. 5. Normalized induction factors for homogenous spheres with radius $R=10 \mathrm{~cm}, 15 \mathrm{~cm}, 20 \mathrm{~cm}, 30 \mathrm{~cm}$ and $50 \mathrm{~cm}$.

合について, 先の人体詳細モデルに対する規格化誘導係数 との比較を, 先の Fig. 3, Fig. 4 に併せてプロットしている。 なお $R=20 \mathrm{~cm}$ は, 人体の断面の最大半径（正面方向の磁界 ばく露時の胴体部）としてしばしば用いられる值に対応す るものである。先に述べたように, 均質球の半径について は任意性があり，この值を調整することにより，詳細モデ ルの規格化誘導係数の上限の值にさらに近づけることがで きるが, 検討配置のケース数や, 磁界発生源の形態が限ら れていることから，現段階ではこれにとどめている。

\section{4. 考察}

〈4·1〉体内誘導量の各種評価指標について 本検討 では, 体内誘導量の評価指標として, 誘導電流密度および 誘導電界のそれぞれについて，「ボクセル最大值」のほか, 「ボクセル $99 \%$ 值」, 電流方向に直交する「 $1 \mathrm{~cm}^{2}$ 断面平均の 最大值」, および, 同「1 $\mathrm{cm}^{2}$ 断面平均の $99 \%$ 值」を算出し た。ここではこれらの評価指標について説明を加える。な お，「99\%值」とは, 人体内の各位置での計算結果を統計上 の母集団として扱い，計算結果を大きい順に並べた場合の 99\%の位置に存在する值である。

ボクセルの「99\%值」は, 「Staircasing Error」あるいは「階 段近似誤差」と呼ばれる, ボクセルを用いた計算上不可避 の誤差 (過大な值として表れる) を除去する目的で, Dawson, Stuchly らにより誘導電界に対し導入が試みられている指標 である(24)。解析解のある単純なモデルによる検討結果に基 づき「99\%」が適当であるとされているが，この考え方の詳 細モデルへの適用の妥当性はなお不明である。

また，電流方向に直交する「 $1 \mathrm{~cm}^{2}$ 断面平均の最大值」に ついては, ICNIRP ガイドライン (1)において, 誘導電流密度 の基本制限の評価方法として採用されていることから，関 心が高い評価指標である。本稿では, 平均化に使用するボ クセルに空気層が含まれる場合, 空気層を除外して平均化 を行ったが，他の手法もとりえることから，平均化手法に ついてはなお議論のあるところである。 
$\left\ulcorner 1 \mathrm{~cm}^{2}\right.$ 断面平均の 99\%值」という指標については, 文献(18) において IEEE 規格 ${ }^{(4)} に$ 明示された均質楕円断面モデルに対 する最大誘導電流と, 人体詳細モデルでの最大誘導電流の 大きさが同等とみなせるように導入された指標であり，ボ クセル最大誘導電流に対する割合は最も小さくなる。

誘導電流密度と誘導電界のいずれが適切かの議論も含 め, どの指標を用いるかにより誘導量そのものの評価值が 大きく異なってくるため, 使用する指標についての合意が 必要となるが，規格化誘導係数を用いることにより，いず れの評価指標を用いてもほとんど差はみられないことは, 規格化誘導係数を用いる手法の利点である。

〈4·2〉全身平均磁界の有効性の検証先に述べたよ うに, ICNIRP ガイドライン(1)では, 非一様磁界ばく露の評 価時に, 全身の磁界の平均值を求めて, 磁界の参考レベル と比較する方法も示されている。本節では, この手法の有 効性について検証する。

検討では, 全身平均磁界を指標とした場合の規格化誘導 係数に相当する係数を計算し，これまでの議論における最 大誘導電流密度を指標とする規格化誘導係数との比較を行 う。磁界発生源として Fig. 2 と同じ 3 通りのものを用い, 日 本人男性モデルを対象に, 全身平均磁界を算出した。つぎ に，この全身平均磁界を指標とした規格化誘導係数に相当 する係数，すなわち，「最大磁界に対する全身平均磁界の割 合」を算出した。Fig. 6 に最大誘導電流密度を指標とする規 格化誘導係数との比較を示す。結果より，この 2 つの評価 指標の差は比較的小さく, 全身平均磁界が, 磁界の非一様 性を評価する良好な指標となっていることが読み取れる。 しかしながら，実際の適用にあたっては，全身にわたる磁 界の平均值を測定により得ることは煩雑であるため, 困難 が予想される。

$\langle 4 \cdot 3\rangle$ 防護指針適合性評価に関する論点＼cjkstart最後に, 一部繰り返しになるが，防護指針適合性評価についての著

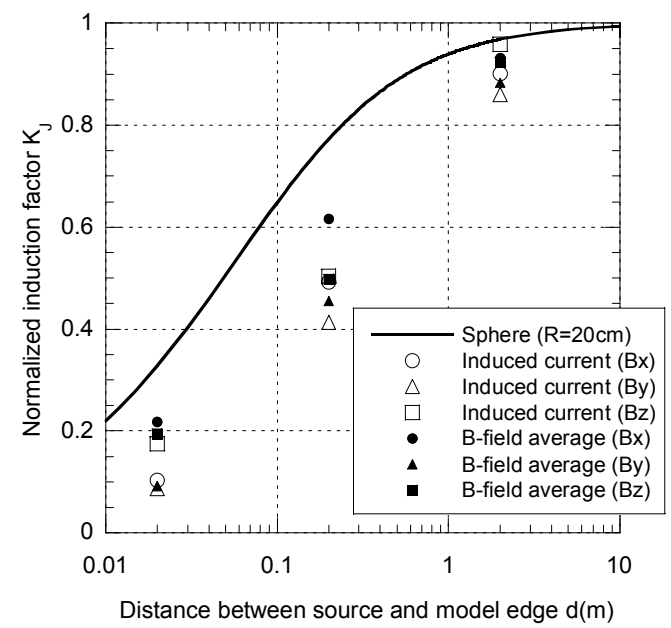

Fig. 6. Normalized induction factors estimated by the "whole body average" of exposing magnetic field. Comparison with the factors based on maximum induced currents (Japanese male model).
者らの論点について整理する。

（1）まず，一様磁界ばく露を想定した場合，防護指針で は, 磁界参考レベルを超えた場合, 誘導電流計算評価を行 い，基本制限との比較評価を行うことになる。しかしなが ら，計算において適用する人体モデルは任意であり，使用 するモデルによって評価結果が大きく異なるため, 評価の 正当性を示すことが困難である。また，結果的に防護指針 に示された基本制限と参考レベルの関係との整合がとれな くなる。

（2）このため, 磁界と誘導電流の換算は, どこかにオー ソライズされた拠りどころ（基準）を求めたい。この際, 適用する防護指針に示された，基本制限と参考レベルの関 係を用いることが, 最も適切で説得力があり, 後述の非一 様磁界ばく露の検討でも矛盾が生じない。

(3) 非一様磁界ばく露に対しても, 誘導電流の直接評価 を行うと一様磁界ばく露と同様に人体モデルの違いが評価 結果に反映され大きく異なる。これに対し, 本論文で示し たように, 一様磁界ばく露の評価值に対する割合（＝規格 化誘導係数。モデル内最大磁界が等しいとした場合）は, モデルの依存性が極めて小さい。

（4）したがって, 非一様磁界ばく露に対しては, 規格化 誘導係数（磁界の非一様性を反映した係数で, モデルに依 存せず，本稿の(5)式が共通に使用できる）を用いて, 最大 磁界の測定值を補正（減ずる方向となる）し, 等価な一様 磁界に換算することで, 防護指針の参考レベルと比較が可 能となる。あるいは, 防護指針の参考レベルに規格化誘導 係数の逆数を乗ずれば, 最大磁界と比較可能な「緩和され た」参考レベルが得られる。

（5）議論からやや逸れるが, 非一様磁界ばく露を扱う学 術論文においても, 非一様磁界ばく露の誘導電流評価結果 とともに, 同じ人体モデル, 数值計算コードを用いた一様 磁界ばく露条件での誘導電流評価結果の併記が推奨され る。これにより, 規格化誘導係数の算出が可能となるとと もに, 評価結果の解釈が容易になる。

\section{5. まとめ}

本研究では, 簡便で妥当な非一様磁界ばく露評価手法の 開発を目的とし, 以下の検討を行った。はじめに誘導電流 数值計算評価により防護指針の基本制限と比較する手法の 問題点を示し, 次にこれを解決する手法として, 磁界の非 一様性の指標となる規格化誘導係数を用いて等価な一様磁 界を求める手法とその利点を示した。次に, 日本人詳細モ デルを対象にインピーダンス法による誘導電流計算を行 い, 規格化誘導係数を算出し, モデル間, 指標間の比較を 行った。この結果, 規格化誘導係数を用いる評価手法では, 使用する人体モデルや評価指標の違いの影響がわずかであ ることを示した。最後に，規格化誘導係数の距離依存性を， 均質球を用いて解析式により簡便に求める手法を示し, 簡 便な非一様磁界ばく露評価手法開発への足がかりとした。

現在までの検討では, 非一様磁界ばく露として限られた 
ケースの単線電流路近傍のみを模擬しているが，今後これ とは異なるさまざまな配置や, 電力線を模擬する 3 相電流 路や機器を模擬する電流ループ（磁気ダイポール）など異 なる形態の磁界発生源に対し, 均質球を用いる本手法の有 効性の確認を行い, 手法の完成度を高めたいと考えている。

\section{謝 辞}

本研究を行うにあたり，日本人人体詳細モデルの提供を いただくとともに，数值計算において有益なご教示をいた だきました, 独立行政法人情報通信研究機構, 渡辺聡一博 士，和氣加奈子博士，長岡智明博士をはじめ同機構の関係 各位に感謝いたします。また, 誘導電流数值計算には, （株） 電力計算センター, 大西浩史氏ならびに小野喜芳氏のご助 力をいただきました。ここに感謝申し上げます。

(平成 18 年 7 月 19 日受付, 平成 18 年 10 月 20 日再受付)

\section{文献}

(1) ICNIRP : "Guidelines for limiting exposure to time-varying electric, magnetic, and electromagnetic fields (up to $300 \mathrm{GHz}$ )", Health Phys., Vol.74, No.4, pp.494-522 (1998)

(2) "Council recommendation of 12 July 1999 on the limitation of exposure of the general public to electromagnetic fields $(0 \mathrm{~Hz}$ to $300 \mathrm{GHz})$ ", 1999/519/EC (1999)

(3) "Directive 2004/40/EC of the European parliament and of the council of 29 April 2004 on the minimum health and safety requirements regarding the exposure of workers to the risks arising from physical agents (electromagnetic fields)" $18^{\text {th }}$ Individual Directive within the Meaning of Article 16(1) of Directive 89/391/EEC (2004)

(4) IEEE : "IEEE standard for safety levels with respect to human exposure to electromagnetic fields, 0-3 kHz", IEEE Std C95.6 (2002)

(5) "Exposure to electromagnetic fields $(0 \mathrm{~Hz}-10 \mathrm{MHz})$ ", Pub 2000/6, Health Council of Netherlands (2000)

(6) T. Nagaoka, K. Sakurai, E. Kunieda, S. Watanabe, H. Honma, T. Suzuki, M. Kawai, K. Sakamoto, K. Ogawa, K. Konokawa, K. Kubota, B. Kim, M. Taki, Y. Yamanaka, and S. Watanabe : "The development of whole-body high-resolution voxel models of the average Japanese adult male and female", J. Jpn Soc. Medical \& Biological Engineering, Vol.40, No.4, pp.239-246 (2002) (in Japanese)

長岡智明・櫻井清子・国枝悦夫 ・渡辺聡一 ・本間寛之・鈴木 保 河合光正・酒本勝之 $・$ 小川幸次・此川公紀・ 久保田勝巳 ・金 鳳洙 多氣昌生・山中幸雄・渡辺 敏 : 「日本人成人男女の平均体型を有寸 る全身数值モデルの開発」, 生体医工学, 40, 4, pp.239-246 (2002)

( 7 ) T. Nagaoka, S. Watanabe, K. Sakurai, E. Kunieda, S. Watanabe, M. Taki, and Y. Yamanaka : "Development of realistic high-resolution whole-body voxel models of Japanese adult males and females of average height and weight, and application of models to radio-frequency electromagnetic-field dosimetry", Phy. Med. Biol., Vol.49, pp.1-15 (2004)

( 8 ) M. A. Stuchly and T. W. Dawson : "Interaction of low-frequency electric and magnetic fields with the human body", Proc IEEE, Vol.88, No.5, pp.643-664 (2000)

(9) P. J. Dimbylow : "Induced current densities from low-frequency magnetic fields in a $2 \mathrm{~mm}$ resolution, anatomically realistic model of the body", Phys. Med. Biol., Vol.43, pp.221-230 (1998)

(10) P. Dimbylow : "Development of the female voxel phantom, NAOMI, and its application to calculations of induced current densities and electric fields from applied low frequency magnetic and electric fields", Phys. Med. Biol., Vol.50, No.6, pp.1047-1070 (2005)

(11) W. Xi and M. A. Stuchly : "High spatial resolution analysis of electric currents induced in man by ELF magnetic fields", Appl. Comput. Electromag. Soc. J., Vol.9, pp.127-134 (1994)

(12) T. W. Dawson, K. Caputa, and M. A. Stuchly : "Influence of human model resolution on computed currents induced in organs by $60-\mathrm{Hz}$ magnetic fields", Bioelectromagnetics, Vol.18, pp.478-490 (1997)
(13) R. Kavet, M. A. Stuchly, W. H. Bailey, and T. D. Bracken : "Evaluation of biological effects, dosimetric models and exposure assessment related to ELF electric- and magnetic-field guidelines", Appl. Occupational Environmental Hygiene, Vol.16, pp.1118-1138 (2001)

(14) J. Swanson : "A transmission utility's experience of applying EMF exposure standards", Health Phys., Vol.83, No.3, pp.417-425 (2002)

(15) M. A. Stuchly and T. W. Dawson : "Human body exposure to power lines: relation of induced quantities to external magnetic fields", Health Phys., Vol.83, No.3, pp.333-340 (2002)

(16) T. D. Bracken : "Assessing compliance with power-frequency magnetic-field guidelines", Health Phys., Vol.83, No.3, pp.409-416 (2002)

(17) W. T. Kaune, J. L. Guttman, and R. Kavet : "Comparison of coupling of humans to electric and magnetic fields with frequencies between $100 \mathrm{~Hz}$ and $100 \mathrm{kHz}$ ", Bioelectromagnetics, Vol.18, pp.67-76 (1997)

(18) T. D. Bracken and T. W. Dawson : "Evaluation of nonuniform 60-hertz magnetic-field exposures for compliance with guidelines", J. Occupational \& Environmental Hygiene, Vol.1, pp.629-638 (2004)

(19) IEC : "Exposure to electric or magnetic fields in the low and intermediate frequency range - Methods for calculating the current density and internal electric field induced in the human body, Part 1: General”, IEC 62226-1 (2004-11)

(20) IEC : "Exposure to electric or magnetic fields in the low and intermediate frequency range - Methods for calculating the current density and internal electric field induced in the human body, Part 2-1: Exposure to magnetic fields - 2D models", IEC 62226-2-1 (2004-11)

(21) IEC : "Measurement methods for electromagnetic fields of household appliances and similar apparatus with regard to human exposure", IEC $62233(2005-10)$

(22) K. Yamazaki, T. Kawamoto, H. Fujinami, and T. Shigemitsu : "Simplified Dosimetry for Human Exposure to Non-uniform ELF Magnetic Field", IEEJ Trans FM, Vol.125, No.7, pp.571-576 (2005-7)

(23) K. Yamazaki, T. Kawamoto, H. Fujinami, and T. Shigemitsu : "Investigation of Relationship between ELF Magnetic Field and Induced Current Inside Human Body", T. IEE. Japan, Vol.120-A, No.3, pp.369-370 (2000-3) (in Japanese)

山崎健一・河本 正・藤波秀雄・重光 司:「低周波磁界と人体内誘 導電流に関する考察一誘導電流換算モデルの比較一」, 電学論 $\mathrm{A}, \mathbf{1 2 0}$, 3, pp.369-370 (2000-3)

(24) T. W. Dawson, M. Potter, and M. A. Stuchly : "Evaluation of modeling accuracy of power frequency field interactions with the human body", Appl. Comput. Electromag. Soc. J., Vol.16, No.2, pp.162-172 (2001)

(25) N. Orcutt and O. P. Gandhi : "A -3D impedance method to calculate power deposition in biological bodies subjected to time varying magnetic fields", IEEE Trans Biomedical Engineering, Vol.35, No.8, pp.577-583 (1988)

(26) K. Wake, T. Tanaka, and M. Taki : "Analysis of induced currents in a rat exposed to $50-\mathrm{Hz}$ linearly and circularly polarized magnetic fields", Bioelectromagnetics, Vol.21, pp.354-363 (2000)

(27) Y. Suzuki and M. Taki : "Measurement of magnetic field from an induction heating hob and estimation of induced current density in human body", IEEJ Trans FM, Vol.125, No.5, pp.427-433 (2005-5) (in Japanese) 鈴木敬久・多氣昌生:「誘導加熱調理器近傍の加熱周波数磁界の測定 と人体誘導電流推定」, 電学論 A, 125, 5, pp.427-433 (2005-5)

(28) Y. Kamimura, M. Kojima, and Y. Yamada : "Induced current inside a spherical model of a human head due to magnetic current sources of AC drive electric shaver", IEICE Trans. Communication (Japanese Edition), Vol.J85-B, No.5, pp.706-714 (2002-5) (in Japanese)

上村佳嗣・小島勝哉・山田芳文 : 「交流式電気シェーバの磁流源の同 定とそれによる頭部内の誘導電流の計算」, 通信学論(B), J85-B, 5, pp.706-714 (2003-5)

(29) H. Tarao, N. Hayashi, and K. Isaka : "Numerical analysis of induced current inhuman head exposed to nonuniform magnetic field including harmonics", IEEJ Trans FM, Vol.123, No.11, pp.1100-1107 (2003-11) (in Japanese)

太良尾浩生・林 則行・伊坂勝生：「高調波を含む不平等磁界による 頭部モデル内誘導電流の解析」, 電学論 $\mathrm{A}, \mathbf{1 2 3}, 11, \mathrm{pp} .1100-1107$ (2003-11)

(30) H. Tarao, N. Hayashi, and K. Isaka : "Averaging treatment of numerically obtained induced currents in human body exposed to intermediate frequency magnetic fields in the vicinity of household induction heater", $J$. IEIE Japan, Vol.26, №.2, pp.142-151 (2006) (in Japanese) 
太良尾浩生・林 則行・伊坂勝生 :「電磁調理器からの中間周波漏れ 磁界による体内誘導電流の解析と平均化処理」, 電気設備学誌, 26, 2, pp.142-151 (2006)

(31) S. Nishizawa, H-O. Ruoss, F. M. Landstorfer, and O. Hashimoto : "Numerical study on an equivalent source model for inhomogeneous magnetic field dosimetry in the low-frequency range", IEEE Trans Biomed. Eng., Vol.51, No.4, pp.612-616 (2004)

(32) S. Nishizawa, F. Landstorfer, K. Matsumoto, and O. Hashimoto : "Magnetic field and dosimetric study at intermediate frequency range using the coil source model", IEICE Trans Electron., Vol.E89-C, No.4, pp.524-530 (2006)

(33) S. Hamada and T. Kobayashi : "Analysis of electric field induced by ELF magnetic field utilizing fast-multipole surface-charge-simulation method for voxel data", IEEJ Trans FM, Vol.126, No.5, pp.355-362 (2006-5) (in Japanese)

濱田昌司・小林哲生：「ボクセルデータ用高速多重極表面電荷法によ る低周波磁界誘導電界計算」, 電学論 A, 126, 5, pp.355-362 (2006-5)

(34) C. Gabriel : "Compilation of the dielectric properties of body tissues at RF and microwave frequency", Technical Report of Brooks Air Force Base, AL/OE-TR-1996-0037 (1996)

山 崎 健 一 (正員) 1968 年 2 月 26 日生。 1990 年 3 月東

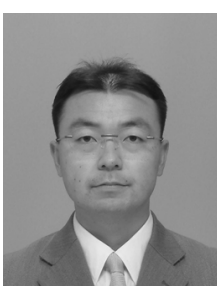
京理科大学理学部応用物理学科卒業。1992 月 3 月北海道大学大学院工学研究科生体工学専攻 修士課程修了。同年 4 月(財)電力中央研究所入 所，主として，電磁環境評価ならびに生体作用 に関する研究に従事し，現在に至る。博士(工 学)。2002 年〜2003 年米国ワシントン州立大学 電気工学科客員研究員。2001 年電気学会論文賞 受賞。IEEE Senior Member，Bioelectromagnetics Society 会員。

河本 正 (正員) 1953 年 11 月 26 日生。1974 年 3 月奈

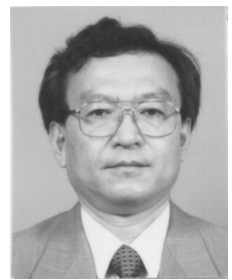
良工業高等専門学校電気工学科卒業。1979 年 3 月東京理科大学理学部 II 部物理学科卒業。1974 年 4 月(財)電力中央研究所入所, 主として, 電 界・磁界計算法に関する研究に従事し, 現在に 至る。博士(工学)。1989 年および 2001 年電気 学会論文賞受賞。IEEE 会員。

藤 波 秀 雄

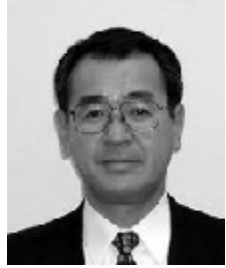

（正員） 1952 年 12 月 2 日生。 1978 年 3 月成 蹊大学大学院工学研究科電気工学専攻修士課 程修了。同年 4 月(財)電力中央研究所入所, 主 として, ガス絶縁機器の絶縁技術, 電力設備の 電磁環境ならびに雷観測技術に関する研究に 従事し, 現在に至る。工学博士。1989 年〜1990 年カナダ・マニトバ大学電気工学科客員研究 員。1989 年, 1994 年および 2001 年電気学会論 文賞受賞。IEEE Senior Member。

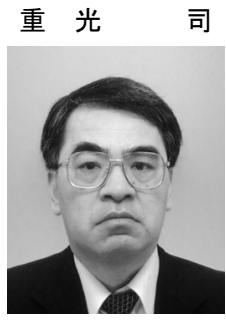

(正員) 1948 年 2 月 27 日生。 1978 年 3 月北 海道大学大学院工学研究科電子工学専攻博士 課程修了。1974 年〜1976 年ドイツ Max Planck 生理学研究所 Assistant Researcher。1980 年 4 月 (財)電力中央研究所入所, 環境問題, 主として 電磁界の生物影響に関する調査研究に従事し, 現在に至る。工学博士。第 40 回オーム賞, 2001 年電気学会論文賞受賞。IEEE 会員, Bioelectromagnetics Society 前 Board Member。 